\title{
NOTES
}

\section{THE CASE OF DR. BOWEN: AN UNKNOWN WHITMAN LETTER RECOMMENDING AN ARMY DOCTOR}

On March 4, 1868, Walt Whitman did a favor for a former U.S. Army Surgeon whom he regarded and had consulted on various occasions. The surgeon was Dr. Charles H. (Henry) Bowen. The favor was a letter of recommendation.

Whitman met many surgeons in his visits to the Army hospitals in Washington during the Civil War. All but a few of these medical men he judged excellent. In an article for The New York Times ("Visits Among Army Hospitals," December 11, 1864, p. 2), Walt wrote: "I never ceas'd to find the best young men, and the hardest and most disinterested workers, among these surgeons, in the hospitals. They are full of genius, too. I have seen many hundreds of them, and this is my testimony."

One surgeon, Dr. Charles H. Bowen, ranked high on Whitman's list of Army doctors. Bowen, born in 1838, resided as a medical student at the Washington Infirmary (afterwards referred to as the "E" Street Hospital) for 29 months from April 1859 to August 1861. On October 7, 1861, he was appointed Medical Cadet, U.S. Army, and assigned to duty at the Washington Infirmary, where, he said, "I dressed the first wounds of the War, April 19, 1861, of the 6th Regt. Mass. Vol."1 Dr. Bowen was transferred to Circle Hospital until October 7, 1862. He then obtained a contract for duty as Acting Assistant Surgeon, U.S. Army, and was assigned to Armory Square Hospital in Washington. ${ }^{2}$ Between 1862 and 1865 Dr. Bowen served under contract at Armory Square Hospital, at the Battle of Fredricksburg in 1862, U.S. General Hospital in Pittsburgh, U.S. General Hospital in Chicago, Fort Simmons (Washington), Fort Mansfield (Washington), Lincoln General Hospital (Washington), and Slough General Hospital (Alexandria, Virginia) until November 11, 1865, when Slough Hospital was closed and Bowen's contract was annulled at his own request. After the War ended he served intermittently as a U.S. Army contract surgeon until 1867. Two case histories of wounded soldiers treated by Dr. Bowen in April 1865 at the Armory Square Hospital are cited in the Medical and Surgical History of the Rebellion, 1861-65 (Washington: Government Printing Office, 1875), II, 444 and 584.

Dr. Bowen's military history was unfortunately marred by a charge of desertion lodged against him after the War on May 1, 1867 by Norton H. Thomas, Captain 24th U.S. Infantry and Bat. Major, U.S.A. - a charge that Bowen years later cleared himself of. On April 18, 1867 Bowen made a contract for duty at the Post of Greensboro, Mississippi. Captain Thomas, Post Commander at Greensboro, received the order assigning A. A. Surgeon Bowen to duty and reported that "said officer has failed to obey said order." Colonel Joseph R. Smith, Medical Director, 4th Military District in Vicksburg, received Thomas's report and on May 4, 1867 sent the following statement to the Surgeon General in Washington: "I believe that Dr. Bowen has deserted in a fit of cowardice induced by seeing a pistol fired, by one man at another, while en route to this place." 3 On the reverse side of this memorandum, received at the Surgeon General's Office on May 12, 1867, is an order (written either to or by Dr. J. S. Billings, Asst. Surgeon): "Who is Bowen? Annul his contract \& put a black mark against his name." 
Dr. Bowen was subsequently blacklisted for "disobedience of order," a status that continued in effect until 1875 and which would have prevented him from entering into any further terms of enlistment as a contract surgeon with the U.S. Army. Apparently Bowen did not seek to obtain another contract nor did he know about the blacklisting since he waited eight years to have the charge removed. Meanwhile, he had returned to Washington, D.C., and set up practice as a private physician, applying to Walt Whitman early in 1868 for a letter of recommendation to the place of Police Surgeon in Washington.

Whitman, who probably knew nothing about the blacklisting either, praised Dr. Bowen in his recommendatory letter as "an intuitive physician." He had often witnessed Bowen treating injured soldiers at the Army hospitals in Washington. Together with Dr. D. W. Bliss, under whom Bowen had served at the Armory Hospital and who Walt felt was one of the best surgeons in the Army, Dr. Bowen is mentioned by Whitman in the draft of a letter to Hiram Scholes in 1867. "Dr. Bliss is practising here in Washington. Dr. Bowen also." 4 That Whitman associates Dr. Bowen with Dr. Bliss after the War suggests Bowen stood out in Walt's judgment from other Army doctors with whom he had a personal friendship. In fact, Whitman went to Dr. Bowen in Washington in January 1869 when he complained of bad spells, ${ }^{5}$ which is testimony to the confidence Walt had in him. Again in August of that year, Walt took his friend Peter Doyle to Dr. Bowen for treatment of a skin rash called "barber's itch."

Whitman wrote his letter recommending Dr. Bowen for Police Surgeon on March 4, 1868. Police Surgeon in Washington, D.C., was traditionally a part-time position, which enabled a doctor also to practice privately. According to Boyd's Directory (1868), three surgeons were employed part-time by the Metropolitan Police. Whitman addressed his recommendation to Dr. W. O. Baldwin. Baldwin was an elected Representative from the 1st Ward to the Washington chamber of the city council (under the original city charter of 1802, Washington and Georgetown each had a separate chamber until 1871). He was also a physician and member of the Board of Health in Washington.

Here is the text of Walt Whitman's two-page letter. ${ }^{7}$

\section{Attorney General's Office. [Letterhead]}

Washington, March 4, 1868

My dear Mr. Baldwin:

I write in reference to a friend of mine, Dr. Charles H. Bowen, of this city, who will soon call upon you personally. He seeks the appointment of Surgeon to the Metropolitan Police here. I have known Dr. Bowen for several years. He was a volunteer U.S. Army surgeon during the war, \& was considered one of the best. I can fully join in the same testimony, as he treated, as physician or surgeon, many a case under my own eye, for days \& even months. $\mathrm{He}$ is a good Union man, of full professional experience, gentlemanly manners, temperate, in the prime of life, - \& I have more than once, when watching his treatment, called him an intuitive physician.

I most strongly recommend him as the right man, \& one without deficiency in any way of the qualifications needed for the place of Police Surgeon.

Should you wish it, I will be glad to wait upon you, to testify further regarding Dr. B.

I send you, dear sir, my friendliest respects \& well wishes,

Walt Whitman. 
There is no record that Dr. Bowen received an appointment to the position of Police Surgeon in Washington, and it is not possible to determine whether the black mark against his name on the military records filed at the Surgeon General's office had any influence on the decision of either Dr. Baldwin or the city council.

In 1875-eight years after having been officially blacklisted-Dr. Bowen made a successful effort to clear his name. He wrote to Major General Joseph H. Barnes of the Surgeon General's office in Washington on October 21, 1875, asking "if any charges are against me, can I do anything to have said charges removed." 8 Assistant Surgeon General Charles H. Crane replied by letter dated October 27, 1875, "There are no means known to this office whereby your record can be changed." 9 On December 14, 1875, Bowen again wrote to Major General Barnes and petitioned him to remove the charges, stating he had been "credibly informed that a stain appears in the records of your office against me, at the termination of my services as Acting Asst. Surg. U.S.A., and feeling desirous of removing if possible the stigma attached to my name from official records ... I have the honor to respectfully call you attention to the following relations of facts, and beg you will give my statement due consideration, and relieve me of any unjustly imputed charge that now rests upon me."10 He went on in his three-page letter to provide an account of why he had failed to report to the Post at Greensboro, Mississippi, on May 1, 1867. It seems while en route from Vicksburg to Greensboro Bowen stopped overnight in Jackson, Mississippi, and received a telegram from his brother-in-law announcing the illness of Bowen's father-in-law and requesting his immediate return. Dr. Bowen decided to go back to Washington, where he reported to the Surgeon General stating the circumstances of his non-compliance of orders. The same Assistant Surgeon Dr. J. S. Billings (to or by whom the order "put a black mark against his name" was written about two weeks later on that May 12, 1867 memorandum received from Colonel Smith in Vicksburg) informed Bowen that his contract would be annulled, as Dr. Bowen had requested. Dr. Bowen ended his letter with the appeal to Major General Barnes to "generously cause a review of facts, and if adjudged 'not guilty' exonerate me from the disagreeable charge now appearing against me." Along with his petition he also enclosed letters of reference from former commanding officers and surgeons under whom he had performed his duties during the War. Exactly one week later, on December 21, 1875, Dr. Bowen received from C. H. Crane, Assistant Surgeon General, the good news that "I am instructed by the Surgeon General to inform you that you are absolved from the charge of desertion and restored to your former status upon the records of this office." 11 Dr. Charles $\mathrm{H}$. Bowen's name was officially erased from the Black List by order of General Crane on December 21, 1875.

There is, incidental to Dr. Bowen's military history, one side note of additional interest. Barely nine days after Walt Whitman wrote his March 4, 1868 letter on behalf of Dr. Bowen for the position of Police Surgeon, he answered an inquiry about a position in Washington from Dr. O. K. Sammis, a physician Walt had known some years earlier in Brooklyn, New York. Responding to Dr. Sammis on March 13, 1868, Whitman wrote: "My dear Doctor, Your note has just come to hand, stating that you intend a visit to Washington, \& desire a situation. My friend, if that is your sole object here, \& you depend upon any thing of that kind, (unless you have some special friend who has great influence, or offices at his disposal,) I seriously advise you against any such enterprise. I myself have no influence at all, 
being a mere clerk, $\&$ of low grade- $\&$ our office is in confusion-the Attorney General having yesterday resigned his place.$- " 12$

Little more than a week earlier Whitman had used his personal influence (as well as office if the Attorney General's letterhead carried authority) - then denied he had any influence or office to use. That the Attorney General, Herny Stanbery, resigned on March 11 to serve as one of President Johnson's counsels during his impeachment proceedings and left the office in confusion provided Walt an excuse that was convenient since it further released him from the favor he had just performed for Dr. Bowen.

Husson College

WAYNE W. WESTBROOK

\section{NOTES}

1 Letter from Dr. Charles H. Bowen to Charles H. Crane, M.D., Surgeon General U.S. Army, dated June 14, 1883 [located in the Volunteer Staff Officers File (Union Army) in the Military Service Records of the National Archives in Washington, D.C.].

2 Acting Assistant Surgeons were usually "contract" surgeons who held no commission but worked under contract for a term of enlistment at each hospital for the salary of $\$ 80-\$ 100$ per month, equivalent to the pay of a first lieutenant or captain.

3 Volunteer Staff Officers File (Union Army).

4 Walt Whitman: The Correspondence, ed. Edwin Haviland Miller (New York: New York University Press, 1961-69), 1:331.

5 An entry in Whitman's address book, located in the Library of Congress.

6 See The Complete Writings of Walt Whitman, ed. Richard Maurice Bucke, Thomas B. Harned, and Horace L. Traubel (New York and London: G. P. Putnam's Sons, 1902), VIII, $40-4 \ln$.

7 The letter is located in the Thomson-Kinney Collection (Archives RG 69:3, Autograph Album No. 1) at the Connecticut State Library in Hartford, Connecticut. It is printed here by permission of the Connecticut State Library Archives.

8 Volunteer Staff Officers File (Union Army).

9 Ibid.

10 Ibid.

11 Ibid.

12 Correspondence, 2:23.

\section{WHITMAN AND SPENSER'S "E.K."}

Rather than evoking censure, Whitman's laudatory reviews of his own poetry have in our time generally enjoyed their readers' good-humored indulgence. For his admirers no justification of the reviews is necessary, while those less patient 